\title{
Paris Rive Gauche Project: (Re)developping the City on the City
}

\author{
Benoît Ernek ${ }^{1}$
}

(Received July 21, 2014 / Revised July 27, 2014 / Accepted July 28, 2014)

\begin{abstract}
Paris hasn't experienced such excitement since the huge changes brought about by Baron Haussmann in the 19th century. Paris Rive Gauche project, started in 1991, is the largest urban project in city ever since, it represents about $1 \%$ of Paris territory. It takes place on a workshops, factories and warehouses area that prospered along the Seine river and the railways in the 19th century. Originally planned as a business quarter, Paris Rive Gauche, developed by SEMAPA for the City of Paris, fosters urban diversity through housing, offices, public facilities, shops, creating a stimulating neighbourhood where 18,000 residents, 30,000 students as well as 60,000 employees will soon croth paths. This project's main principles are urban and social diversity, deployment of public facilites, the development of new university campus inside the city, promotion of industrial patrimony and connecting the old 13th distict to the river and the opposite side. Half of the project is going to be built on a concrete slab that covers the railway tracks which is one of the major performances of this long-term project. This concrete slab represents the new level of the City, about 6 to 8 meters above the railway tracks. We distinguish three families of buildings on the cover : Classic buildings; Bridges buildings and Connection buildings, these last guarantee the linkage between old and new level of the City.
\end{abstract}

Key words: Paris Rive Gauche, Urban Planning, Covering Railways, Urban Diversity, Bridge Buildings

\section{Introduction of Parisian Urban Context}

An urban renewal project on the scale of Paris Rive Gauche must be placed in the historical context of how Paris has been transformed since the nineteenth century. Certain changes to the city's urban landscape are important to understand its evolution.

Unlike other major cities such as London, Chicago, Lisbon or Tokyo, the city of Paris has never been destroyed. Vestiges of medieval Paris still remain, as do the first attempts at urban planning in the city, which date back to the seventeenth century. Paris as it appears today has its roots in the French Second Empire (1852-1870), when emperor Napoléon the Third and his prefect and Urban Planner Haussmann undertook a series of major renovations to the cityscape. These renovations affected the French capital from its heart to its outer edges, and included the addition or transformation of nearly every aspect of the urban landscape, from streets and boulevards to sewers and water drainage systems, from street furniture and outdoor fixtures to green spaces and public monuments. Up until then, the city had maintained the same footprint, with buildings added and demolished in a more or less organic process. Due to population growth, unhealthy conditions, and narrow streets, the new landscape of Paris was characterized by open spaces and evenly proportioned buildings that stood along broad, tree-lined boulevards and avenues laid over the old network of streets.

The next wave of change came at the beginning of the twentieth century and continued through the First World War. Land once used for market gardens was zoned for residential housing, creating new districts within the bounds of the city's old fortification. The thirty years of continued economic expansion following the Second World War led to further urban growth. A highway system was built and large-scale construction programs transformed the landscape of the greater Paris region. A civic planning policy adopted in 1961 broke with traditional Haussmann-style design, focusing instead on more practical considerations. High-rise developments were a hallmark of this new policy and included the Front de Seine district as well as the Italie and Olympiades sectors of the 13th "arrondissement" (district). Work also began on what is perhaps the most famous of these developments, the La Défense district, which extended Paris to the west. Developments on the eastern edge of the city were also discussed and a network of industrial warehouses was built along the Seine River. The oil crisis of 1974 stopped many of these projects in their tracks. At the same time, residents gained awareness of the impact rapid change was having on certain districts of nation's capital. Citizens rallied against some architectural projects, such as the Montparnasse

1) Architect-Urban Planner, SEMAPA, France (Corresponding author: bernek@semapa.fr) 


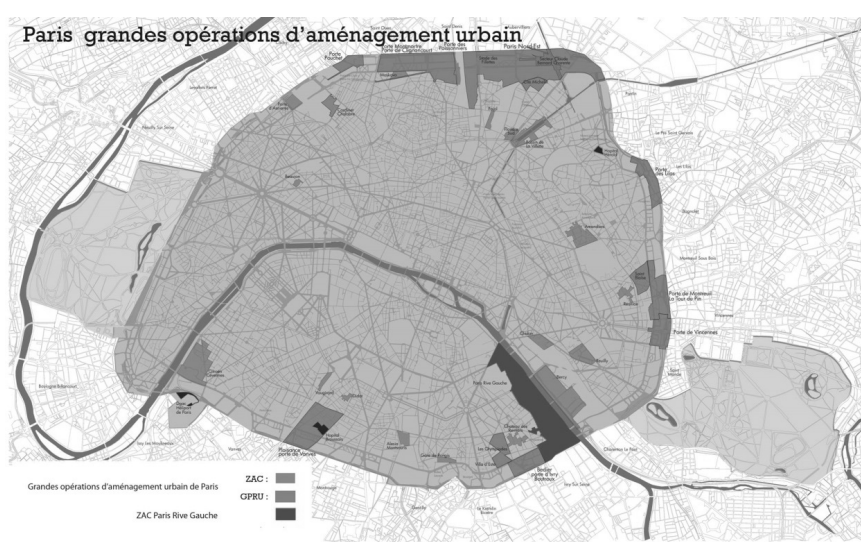

Fig. 1. Urban Planning Areas in Paris Source: data from APUR - Atelier Parisien d'Urbanisme

skyscraper or the demolition of Les Halles, the city's central open-air market. Public outcry stopped several projects that took a "clean state" approach to urban development. With the exception of the Pompidou Center and continued work on La Défense; large-scale urban development projects in Paris slowed or came to a halt.

Following on the heels of the functional high-rise model, proponents of a return to more traditional urban model turned to the urban block model, inspired by Haussmann-style civic planning. Paris Rive Gauche illustrates another trend in Paris city planning : the integration of a contemporary architecture signature with a more traditional vision. This is manifest in the Haussmann-style city blocks lining the Avenue de France, in the building's alignment with the street, and in the dimensional harmony and balance of courtyards and inner gardens.

\section{Paris Rive Gauche Project}

Paris Rive Gauche was shaped by the original use of land on which it is being developed. The site covers 130hectares (about 320 acres) and was once used by rail and industry. Its major asset is undeniably its location within Paris. The Austerlitz Train Station, a flagship of the project, is less than three kilometers (1.8 mile) from the city center (measured from Notre Dame Cathedral). The site fronts the Seine River for more than 2 kilometers (or just over a mile)

In the early 1990's before the construction of the Bibliothèque de France (National Library) and the first office and residential buildings, the area was practically unoccupied, made up of abandoned industries, old warehouses and interlacing railways lines. At that time, Les Frigos, the SNCF's (Train Company) old refrigerated warehouse, had already been converted into artist's studios (similarly, Les Grands Moulins de Paris buildings, an old flour mill, have been converted into the university campus).

One of the development plan's core goals was to reduce the railway's footprint in the zone by constructing a platform over the

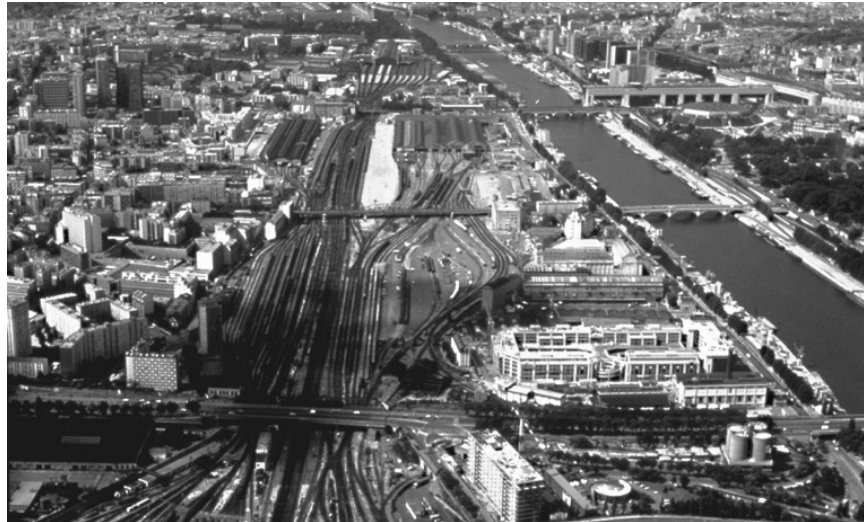

Fig. 2. Paris Rive Gauche in 1991 Source: SEMAPA

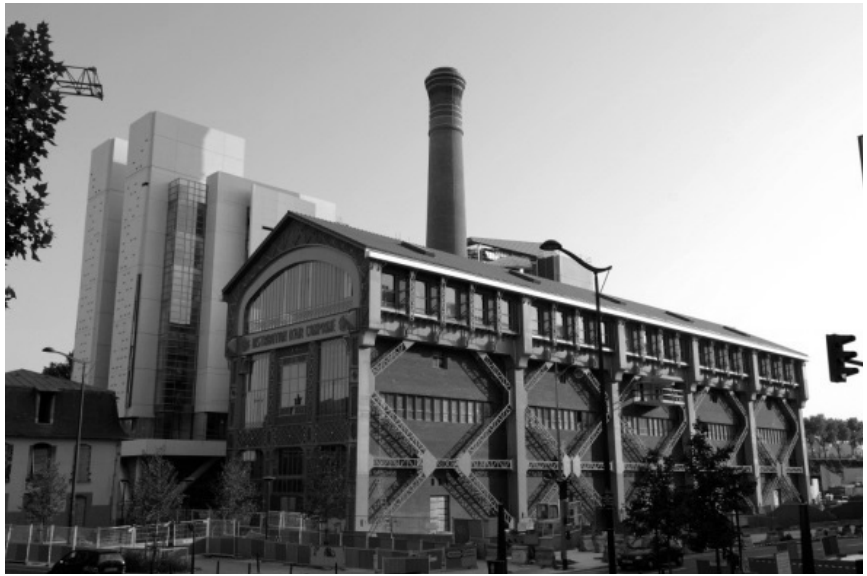

Fig. 3. SUDAC Factory - Architecture School Source: SEMAPA

tracks leading to the Austerlitz Station without impeding their use. The Avenue de France runs over this platform, forming the project's "backbone" (the avenue is a bridge above the railways). Streets running perpendicular to the Avenue de France link the area to the rest of Paris and create a smooth transition to the existing districts in the 13th district and the Seine riverfront. Before, some 60 hectares (150 acres) of the zone were occupied by railway equipment and tracks; now, only those installations strictly necessary for Austerlitz Station to function and grow in the mid-term have been maintained (today, the station serves 15 million passengers annually, it should be serving 40 million in 2040. 28 hectares ( 70 acres) of railway installations have been maintained, freeing up to 32 hectares ( 80 acres) for other uses.

When it embarked on the Paris Rive Gauche Project in 1991, the City of Paris set five major goals for SEMAPA (urban developer of the area) :

- Create jobs to the east of Paris through the construction of a hub of offices that should house $700,000 \mathrm{~m}^{2}(7.5$ million square feet) of office space and about 60,000 jobs by the project's completion. 
- Link the 13th arrondissement (district) to the Seine riverfront by covering rail tracks and providing perpendicular passageways to the space created by this "urban balcony".

- Variations in land grade and topography must be taken into account to accomplish this. The Avenue de France was built over pre-existing rail lines. As a result, it is higher than the areas that border it : the Seine River is on one side and the existing district on the other. Perpendicular roads and pathways built between help offset this difference in grade.

- Bolster economic growth in the capital by creating a hub of service-sector jobs to maintain the city's competitive edge among other major European cities.

- Foster urban diversity. Along with office buildings to create jobs, we are building about 7,500 housing units with the capacity to house 22,000 people. At the same time, public facilities such as schools and nurseries, are being built to draw residents to this new district. Two major entities, the Bibliothèque de France and a university campus, perform the same function.

- It should be noted that locating a 30,000 students university campus near the National library, with easy access to office space and housing, will be a major accomplishment for Paris and the region. For the past 30 years, universities have been developed mostly outside Paris. In Paris Rive Gauche, the university occupies old converted warehouses and new residential and office buildings, creating an area of perpetual activity.

- Finally, the Paris Rive Gauche project has for the past several years operated in keeping with the principles of sustainable development. Builders must follow certain guidelines like :

- $\mathrm{CO}_{2}$ and greenhouse gas emission must be reduced by limiting energy needs for heating and cooling in buildingscurrently, French law sets an upper limit for energy consumption of $50 \mathrm{~kW} / \mathrm{h}$ per square meter par year (about $4.6 \mathrm{~kW} / \mathrm{h}$ per square foot per year);

- Renewable energy sources should be fostered;

- Rooftop rainwater collection;

- In addition to these environmental criteria, the concept of sustainable development encompasses social considerations such as consulting with local non-profits, residents and visitors of the district.

\begin{tabular}{l|l}
\hline Housing & $\begin{array}{l}585,000 \mathrm{~m}^{2} \\
(6,000 \text { family units and } 1,500 \text { student units })\end{array}$ \\
\hline Office space & $750,000 \mathrm{~m}^{2}$ \\
\hline $\begin{array}{l}\text { Private facilities, retail } \\
\text { establishment, business spaces }\end{array}$ & $405,000 \mathrm{~m}^{2}$ \\
\hline Public facilities & $\begin{array}{l}650,000 \mathrm{~m}^{2} \\
\text { (including National Library }\left(250,000 \mathrm{~m}^{2}\right) \\
\left.\text { and university }\left(210,000 \mathrm{~m}^{2}\right)\right)\end{array}$ \\
\hline Parks and gardens & 10 hectares \\
\hline
\end{tabular}

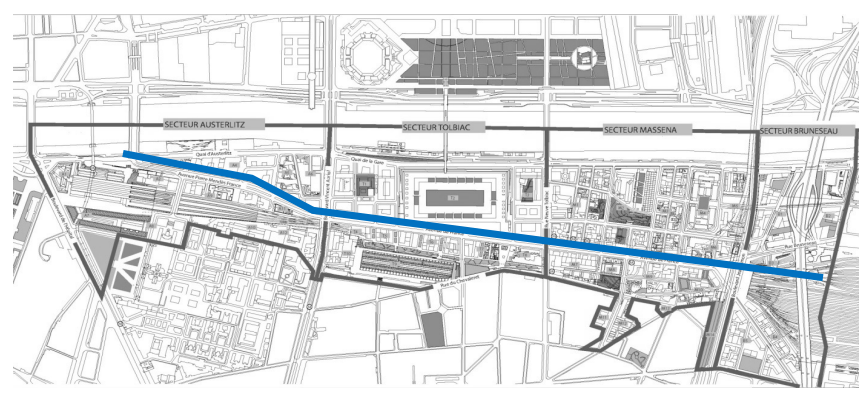

Fig. 4. Paris Rive Gauche "Urban Units" Source: SEMAPA

Paris Rive Gauche is developing 2.45 million square meters (about 26.4 million square feet) of space. The program is proof positive of the city's determination to foster urban diversity in the area. The development detailed below is underway and currently $60 \%$ completed :

A great many urban planning projects have organized urban developments around a large central green space. Paris Rive Gauche uses an entirely different approach, adapted to the projected duration of the program and the phased building of areas.

Its goal is to keep the project from looking like a perpetual construction site for the district's first wave of residents and commuters. As a result, the operation has anchored each area around its own public spaces and facilities (schools, green spaces, shops, etc.), allowing each area to function autonomously. Development is phased so that each area is built as an independent unit within a larger operation.

In the framework of the 1991 Public Agreement between the City of Paris and SEMAPA, the developer's mandates and commitments are described very precisely. These mandates cover each phase of the process, from land acquisition through the management of financing. It is SEMAPA's responsibility to acquire the necessary land for the development, to deploy architectural and civic planning studies, to build infrastructure, and finally, to sell land and building rights to public and private operators.

\section{Urban Planning and Architectural Studies}

Urban planning for the Paris Rive Gauche project is headed by a number of coordinating architects selected through from a series of competitions organized by SEMAPA over the years. A coordinating architect is responsible for designing the special organization of areas following certain major guidelines set at the outset of the project and codified by the PLU plan (local governmental framework for land and development).

For Paris Rive Gauche, we chose to divide up the role of chief urban planning consultant, foregoing the option of a single architect-in-chief responsible for the project over its entire 25-30 year duration. Instead, we currently have 10 coordinating architects, 
each of whom is in charge of a given area in Paris Rive Gauche. This choice was motivated by the following reasons :

- We wished to avoid an overly uniform and therefore narrow vision for the design of a significant part of the nation's capital,

- We wished to honor the individual identity of the different areas, each of which is organized around a landmark :

- The Austerlitz Station (Bernard Reichen is responsible for anchoring this project within the City center of Paris, and harmonizing the classical lines of la Pitié-Salpêtrière (17th Century), a major city hospital located nearby the Station. Christian Devillers is creating continuity with the Seine waterfront near the Paris center. The AREP/Jean Nouvel team is ensuring the station's integration and development over the medium and long-term within the overall context of the operation)

- The Bibliothèque Nationale in the Tolbiac area (Roland Schweitzer is the coordinating architect)

- The Halle Freyssinet in south Tolbiac (Pierre Gangnet is the coordinating architect)

- The university in the north Massena area (see Christian de Portzamparc' fascinating illustration of the open block concept)

- The INALCO Institute and the BULAC Library in south Massena (Bruno Fortier is the coordinating architect)

- A link to the neighboring city of Ivry-sur-Seine in the Masséna-Bruneseau area will be developed with a new generation of skycrapers (architect and urban planner Yves Lion - Ateliers Lion - is heading this project).

- A coordinating architect is not responsible for the buildings within the area that he or she is in charge of, but rather oversees the spatial organization. This includes distribution of public and private spaces, definition of ground rules in the form of stipulations applicable to each construction project and cooperation with SEMAPA to ensure diversity of construction programs within the area.

- These guiding principles have become apparent as the urban landscape evolves. A play of contrast is emerging among the different areas as well as within them. In each area, a common respect for the coordinating architect's guidelines and project stipulations has fostered a range of diverse architectural styles. These shared ground rules have in no way impeded the individual creativity of the executive architects.

\section{Buildings Infrastructure - Covering Railway Tracks}

One of the developer's jobs is to build infrastructure, which must be planned and coordinated with public service concessions such as waste treatment, electricity, water, etc.

Given the original state of land on which Paris Rive Gauche is

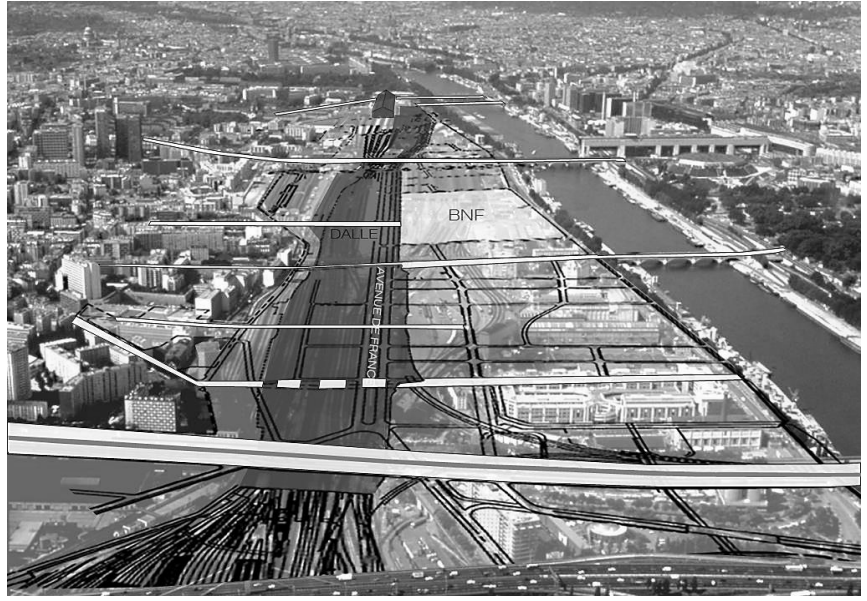

Fig. 5. Paris Rive Gauche's Cover Source: SEMAPA

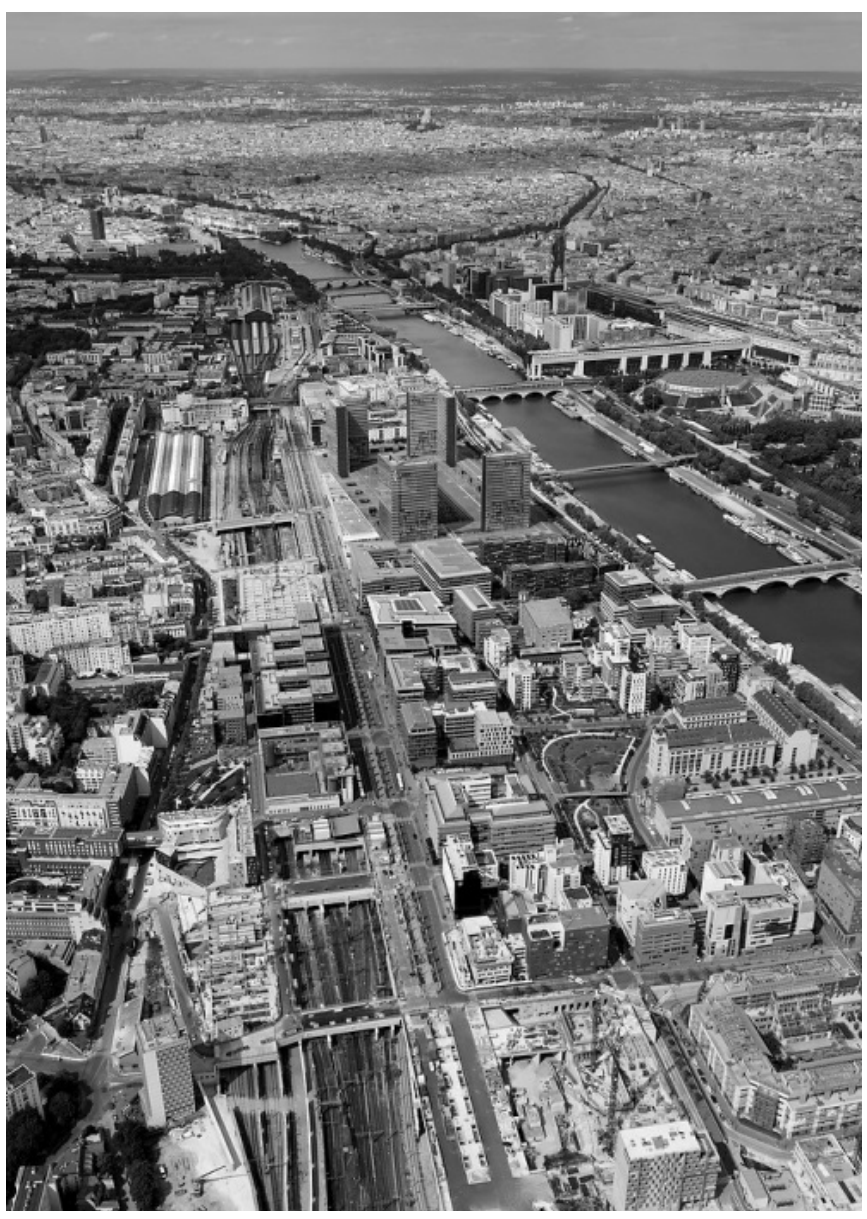

Fig. 6. This New "connection" is Partly Completed between the Massena area and Old Streets Source: SEMAPA

located, building infrastructure is a large scale and complex process, in particular the work related to covering the rail lines.

The SNCF (Train Company) cannot interrupt its public duty as a provider of passenger transport during construction. Continuity 


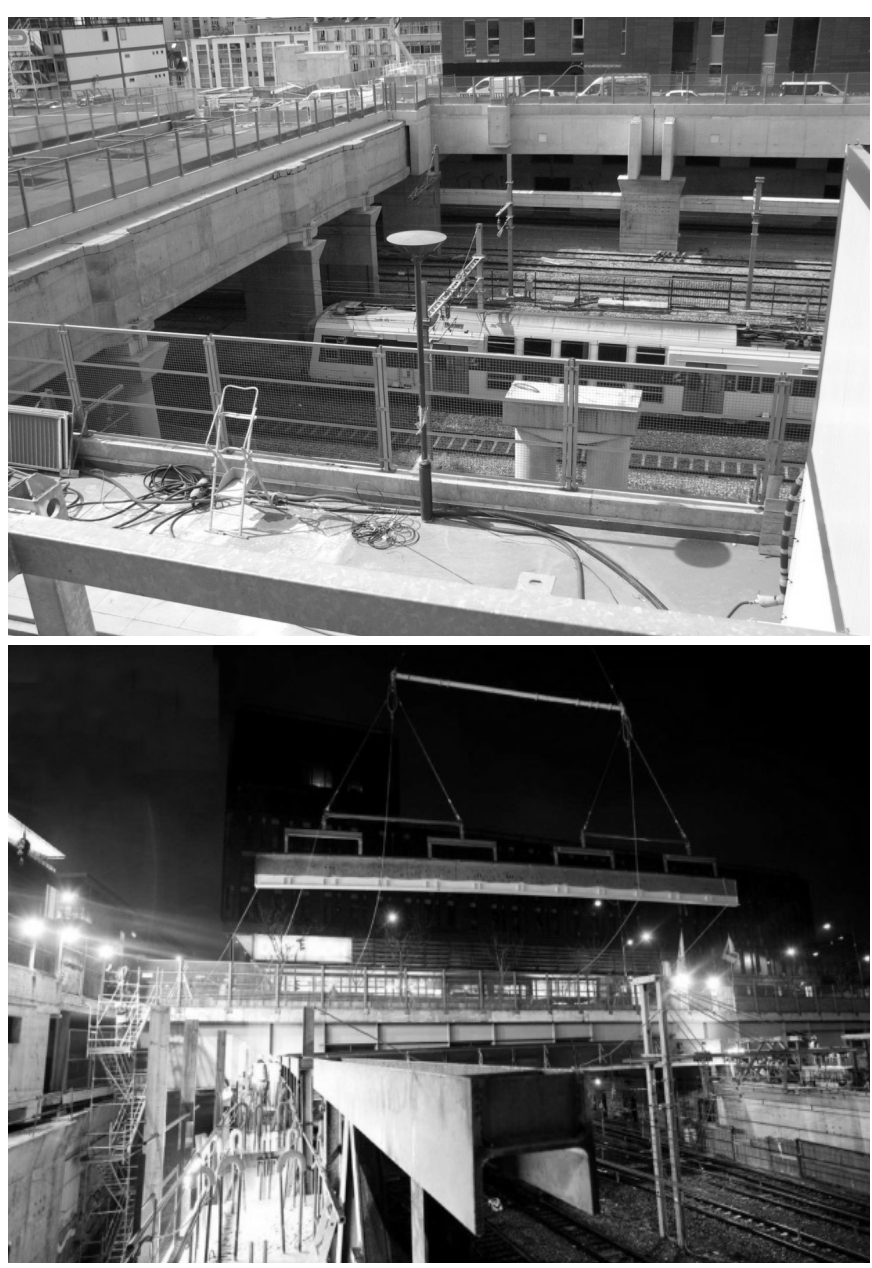

Fig. 7. Covering Railways Source: SEMAPA

of service therefore imposed heavy constraints on the process of covering the railways, which was planned on a careful and tight schedule. The schedule was diligently negotiated with the SNCF and it has a major impact on the overall length of the construction process. Furthermore, the section of the operation to be built on top of the platform covering the railways had to be sketched out before the platform's construction, since its structure would have to bear the load of whatever was built on top of it : this includes buildings, open spaces, gardens, and streets. All of these elements affected the platform's design.

Covering railways may have several goals. First of all, it could be only to separate the railway to reduce noise pollution. But in urbanism, covering railways may permit to gain additional land especially in a city where land is a precious and rare resource.

In Paris Rive Gauche, covering railways was not only to create new land plots, it was also a way to (re)link two districts of the city of Paris and to return the embankment to people. In so far that the link between the "old" 13th district and "new" 13th district shows an important difference in level, about $8 \mathrm{~m}$ high, the cover contributes to sew together these parts of the district.
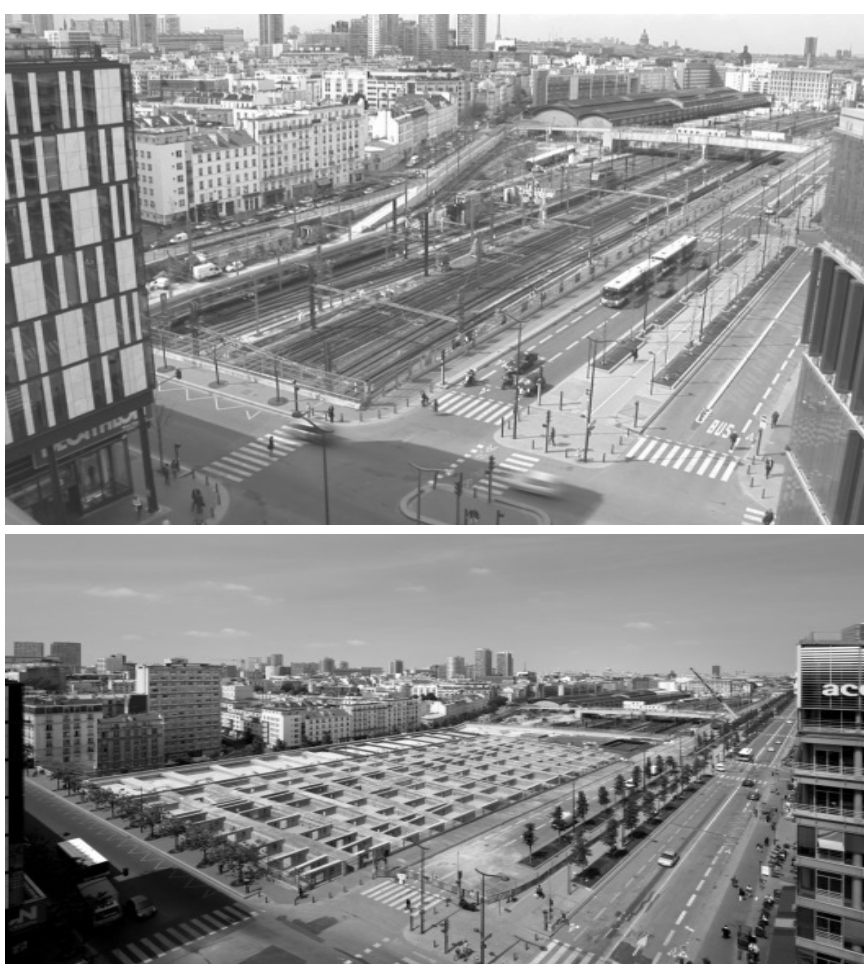

Fig. 8. T8's Building Cover Source: SEMAPA

First imperative in a project that covers railways is anticipation. Indeed, the columns, which are going to carry the cover under railways, have to be established in the final tracks position. Yet the railway network of Austerlitz station we are covering is still changing, in particular to be able to welcome a new high speed line. The timetable of tracks moving is an important element that gives rhythm the progress of the urban project.

The "new" city level, mainly a concrete slab, leans on columns which look like more long and parallel walls between railway tracks. Those walls are created by night without train delays. Beams are constructed beside the rail network and need large space to be created. They are "pushed" on the walls and a lower "ceiling" is set up to isolate the railway network.

The average thickness of the structure is from 1.50 to $3 \mathrm{~m}$ large (even more to support a 16 story building). The structure must also preserve a height of up to $5.50 \mathrm{~m}$ for the trains. The cover level must also respect the surrounding level of the previous streets in order to link "old" and "new" districts. Those two limits define the real thickness the cover could have. Because of the thickness variations, the cover of the railway network is made of many covers mixing reinforced concrete beams and steel beams.

Buildings on top of the cover must be well insulated from solid-borne sound and vibrations from railroad traffic. Transmissions may be reduced by several techniques. In Paris Rive Gauche we mostly use "box springs" that disconnect the building from the cover.

Sometimes, the thickness can be used by property developers 


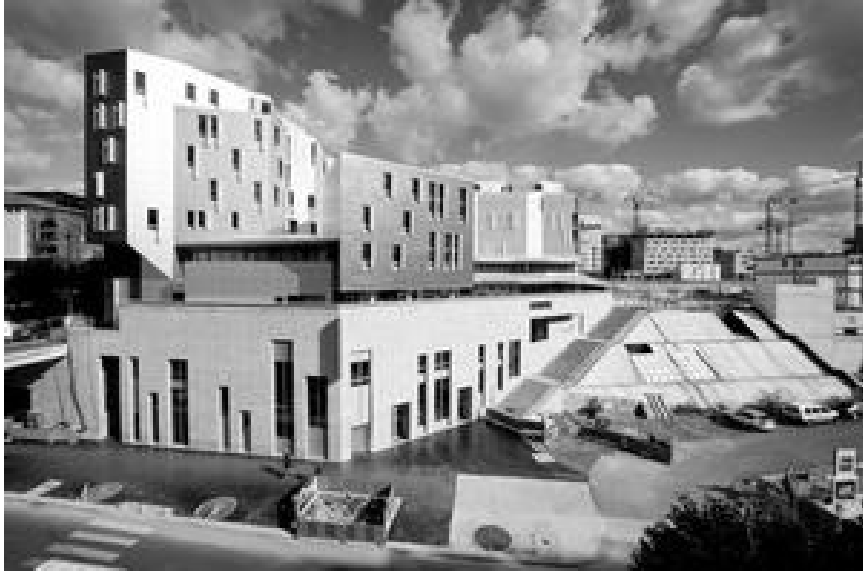

Fig. 9. M9C - School, Theatre and Housing Source: SEMAPA/RIVP Arch: BP architectures

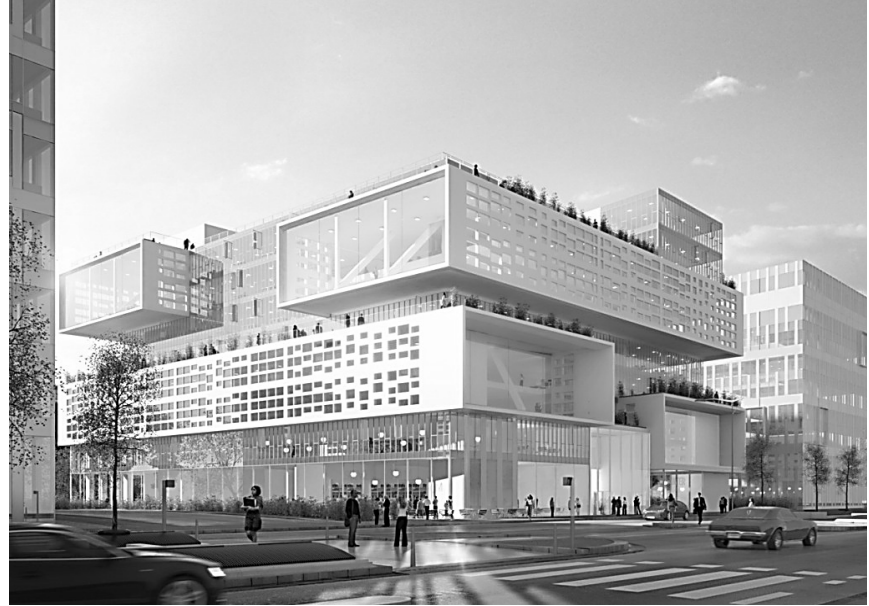

Fig. 10. T6C Building

Source: Marc Mimram/ICADE/SEMAPA

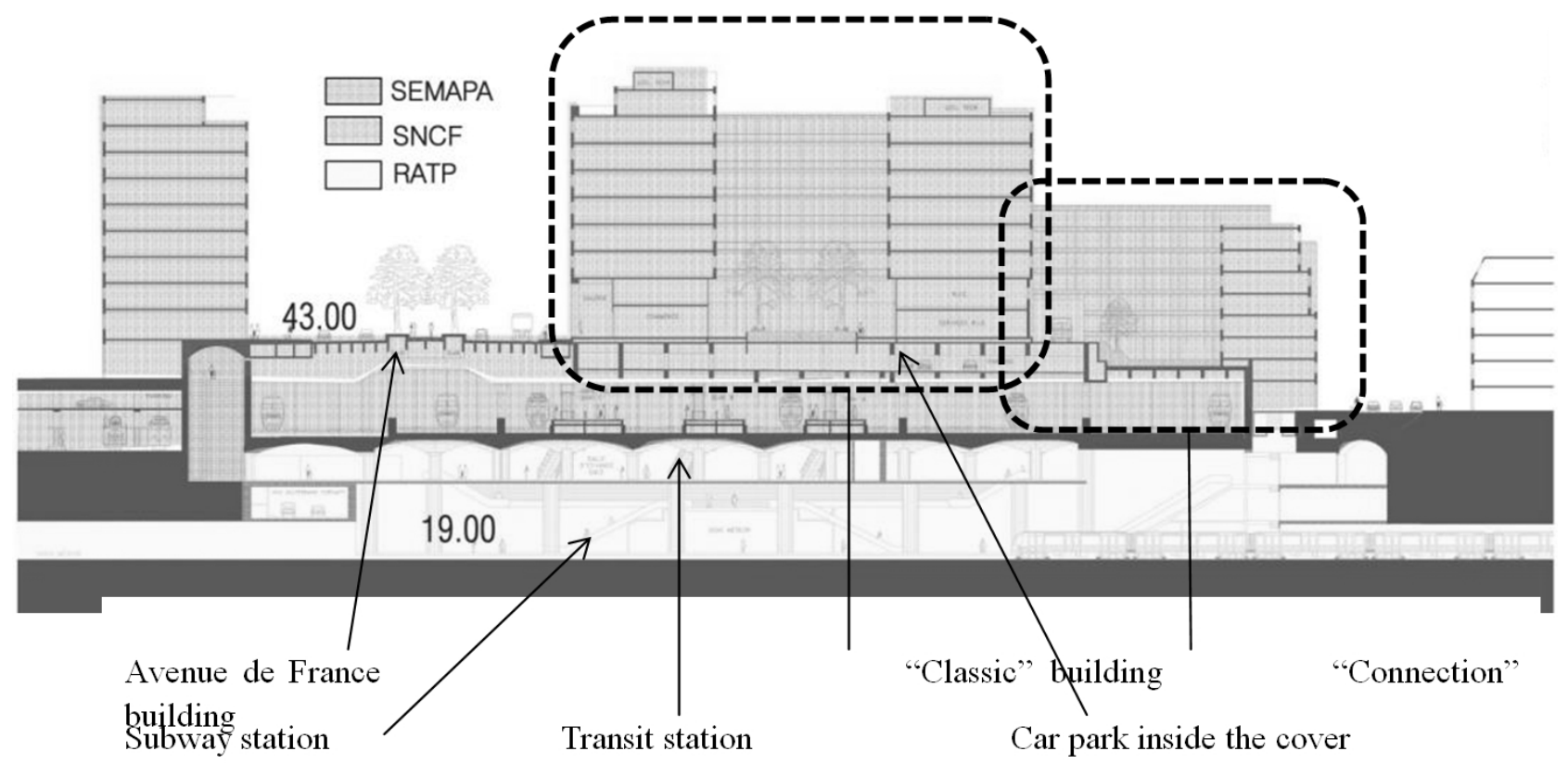

to create a car park, equipment rooms or basements. When streets are created on the cover, we use the thickness for utilities networks or tree pits.

Through the cover of the railways and even through the buildings placed on that cover are exhaust chimneys and smoke ejection holes from the railway up to the sky.

Buildings on the cover must respect weight restraints and chimney locations as preconditions before architectural study. In the Paris Rive Gauche project, SEMAPA completed pre-operational studies in order to anticipate the needs of the future program in order to create the cover before selling the urban rights to a property developer. These constraints are imperative to the building developers (they are written in the sale contract).
We distinguish three families of buildings on the cover : "Classic" buildings; Bridges buildings and Connection buildings.

"Connection" buildings guarantee the linkage between the "old" and "new" level of the City. The first building, called M7B, was designed by architects Brenac \& Gonzalez. This residential building straddles the railway network, being half on the cover and half on a regular plot along the tracks.

To connect the building with the previous street, shops are created between the street and the railway tracks. Structure disconnection (insulation from solid-borne sound and vibrations) is performed on the shop level before the first living floor.

The last "connection" building is called M9C and stacks a theatre, connected to the previous street, a junior school, connected 
with the "new" level and housing in the top floors.

These buildings generally have a level entrance (referring to the previous and new streets) ; the main challenge is to manage a program in the lower floor that can be close to the rail network with less insulation like shops or offices.

Also the definition of volume estates is really difficult notably because of the interweaving between the rail network and the building.

"Classic" buildings stand on artificial land plots, these buildings look like regular buildings but their conception must respect the constraints referenced above. Definition of the property includes the cover of the railways minus a few centimeters above the tracks to hang catenaries and other equipment.

"Connection" and "Classic" buildings need a long process before delivering the buildings (pre-operation studies, creation of the walls, coverings the tracks, then building), in order to reduce the construction calendar and also to be able to build when the thickness of the cover is really limited, SEMAPA develops the next step : "Bridge" buildings.

"Bridge" buildings will be realized in the Tolbiac area (in front of the National Library). The first building, called T6C, is an office building designed by Marc Mimram and will be built next year.

This building will create his own "cover", the beams will be included inside the buildings like a regular bridge. More exactly, T6C is a living beam.

This conception allows to save time by avoiding the realization of a "regular" artificial cover.

\section{Conclusion}

We have drawn several valuable lessons from our experience at the head of the Paris Rive Gauche project. Through none of them may be directly transposed onto another operation, they open up several avenues for discussion and reflection.

In a major urban development operation where the local government takes the initiative and retains responsibility for its management over time while giving the developer significant power to decide and to act, it is important that the latter agree to share its power with all those participating in the project.

We have now moved away from prescriptive ideas of civic planning to a more strategic model of urban design. Openendedness and flexibility are essential if urban renewal projects are to adapt to structural changes such as evolving lifestyles, social patterns, and culture; changes in the needs of modern businesses; and the ups and downs of the economic climate.

It now seems evident that in financing urban development, risk must be shared among the largest possible number of stakeholders, working together in partnership. Forging partnerships with landowners is particularly necessary given the growing cost of land within these operations. Building such partnerships with the private sector is equally necessary, as this sector generates a significant proportion of the development project's revenues, and thus its force and resilience on the market and in the local and national economies.

Finally, a developer's approach must be compatible with the local democratic process, which means guaranteeing transparency and ensuring residents and users are consulted and involved in the project. After all, the end goal of development projects is meeting the needs of residents and ensuring comfort and happiness in a high-quality environment. 